\title{
Evaluation of Super-ovulatory Protocols in Jamunapari Goats with Pregnant Mare Serum Gonadotropin (PMSG) to Achieve Fecundity Comparable to Black Bengal Goats
}

\author{
D. Sengupta* \\ Department of Livestock Production and Management, West Bengal University of Animal and \\ Fishery Sciences, Kolkata, India \\ *Corresponding author
}

\section{A B S T R A C T}

The present study was an attempt to increase the fecundity of Jamunapari goats making it comparable to Black Bengal goats. Anestrous Jamunapari does $(n=10)$ were selected those had kidded two to two and half months back and divided into two groups namely JP500 $(\mathrm{n}=5)$ and JP1000 $(\mathrm{n}=10)$. JP500 and JP1000 groups were primed with $50 \mathrm{mg}$ hydroxy-

Keywords

PMSG, HCG,

Fecundity,

Progesterone,

Jamunapari, Black

Bengal, Goats

Article Info

Accepted:

10 October 2020

Available Online:

10 November 2020 progesterone caproate and after three days received intra-muscular injection of $500 \mathrm{IU}$ and 1000 IU PMSG respectively. The does were detected for the symptoms of estrus thrice daily. They were administered intra-muscular dose of 250 IU HCG at the onset of estrus. JP $(n=5)$ and BBG $(n=5)$ group constituted Jamunapari and Black Bengal goats those came to estrus naturally and received no treatment. On the tenth day of estrus (day $0=$ the day of onset of heat), blood samples were collected from all groups for progesterone assay and the number of corpora lutea counted by trans-rectal ultrasonography. Number of kids born in each group was also recorded. The ovulation rate in Jamunapari does differed significantly with $1000 \mathrm{IU}$ and $500 \mathrm{IU}$ dose of PMSG $(5.6 \pm 0.6$ vs $4.2 \pm 0.37$ respectively). Black Bengal goats (BBG group) returning to heat naturally had higher ovulation rate than Jamunapari (JP group) goats. The tenth day progesterone concentration of JP500 and JP1000 group was $10.37 \pm 0.7$ and $12.02 \pm 0.8$ respectively that did not differ significantly but the values for JP1000 was significantly greater than the non-treated Jamunapari does (JP group; $8.48 \pm 0.7$ ). The kidding rate of JP-500 and JP-1000 groups was $2 \pm 0.5$ and $2.8 \pm 0.4$ respectively that differed significantly from the non-treated group (group JP; $1.4 \pm 0.2$ ) and had non-significant difference between BBG group ( $2 \pm$ 0.3). Thus from this study it can inferred that the fecundity of Jamunapari does can be successfully increased and made comparable to Black Bengal goats by the treatment of PMSG and HCG.

\section{Introduction}

The present study has been taken up to test the prospects of Jamunapari goat rearing in
West Bengal by improving its kidding percentage. Black Bengal goat, a local breed of West Bengal is popular for having more number of twins and triplets than other Indian 
breeds. However, this is a dwarf breed with slow growth rate averaging $1.01 \mathrm{~kg}$ at birth, $7.41 \mathrm{~kg}$ in six months and only $12.4 \mathrm{~kg}$ in twelve months period (Paul et al., 2011) compared to $3.7 \mathrm{~kg}, 18.6 \mathrm{~kg}$ and $39.7 \mathrm{~kg}$ in respective periods in Jamunapari goats (Rout et al., 1999). Black Bengal goats make up this demerit by being more fecund than Jamunapari goats. However being a poor milk yielder, Black Bengal goats are often not in a position to maintain the higher number of kids (especially triplets) born. Therefore an attempt has been made to improve the conception rate as well as the kidding percentage of Jamunapari goat through simple treatment protocols that can be easily adopted by the farmers.

\section{Materials and Methods}

Anestrous Jamunapari does $(\mathrm{n}=10)$ having kidding within $2-2 \frac{1}{2}$ month were selected (confirmed by progesterone level below 0.5 $\mathrm{ng} / \mathrm{ml}$ on paired serum samples taken 12 days apart) form Madhavpur village in North 24 Parganas District of West Bengal. These goats were supplied to the farmers through a Government Scheme. These does were primed with $50 \mathrm{mg}$ i.m. hydroxyl progesterone caproate (Inj. Gestasafe ${ }^{\circledR}$, Vet Mankind, India). They were then divided into two equal groups. Group JP500 $(n=5)$ and JP1000 $(n=5)$ received intra-muscular dose of 500 IU and 1000 IU Pregnant Mare Serum Gonadotropin (PMSG; Folligon ${ }^{\circledR}$, Intervet, India) respectively three days after hydroxy progesterone caproate injection. The does were checked in the morning, evening and night for the symptoms of estrus viz. frequent bleating, flagging of tail, reddened vulva and mucus sticking to the tail, At the onset of estrous the does received an intra-muscular dose of 250 IU Human Chorionic Gonadotrophin (HCG; Chorulon ${ }^{\circledR}$, Intervet, India). Group JP $(n=5)$ and group BBG $(n=5)$ constituted Jamunapari and Black Bengal does respectively those came to heat naturally and received no treatment. Twelve hours after the onset of estrus the does were mated with a group of fertile bucks $(n=5)$.

At day 10 of estrous cycle (day $0=$ day of estrous) the ovaries were examined by transrectal ultrasonography (SIUI, China) for the number of corpora lutea along with collection of blood samples for progesterone assay by Enzyme Linked Immunosorbent Assay (Biogenix ${ }^{\circledR}$, India). Number of kids born in each group was recorded and data analyzed by ANOVA.

\section{Results and Discussion}

The ovulation rate in Jamunapari does differed significantly with $1000 \mathrm{IU}$ and 500 IU dose of PMSG $(5.6 \pm 0.6$ vs $4.2 \pm 0.37$ respectively in JP-1000 and JP-500 group; Table 1). Black Bengal goats (BBG group) returning to heat naturally however had higher ovulation rate than their Jamunapari (JP group) counterpart (Table 1). Pampukidou et al., (2011) also found that the ovulation rate was greater in does with higher dose of gonadotrophin.

Though the number of kids born among the various treatment groups (Table 1) was not statistically significant, however independent t-test revealed significant $(\mathrm{P}<0.05)$ difference in kidding rate between PMSG treated groups (groups JP-500 and JP-1000; $2 \pm 0.5$ and 2.8 \pm 0.4 respectively) and non-treated group (group JP; $1.4 \pm 0.2$ ).

Moreover the kidding rate of gonadotrophin treated Jamunapari goats (groups JP-500 and JP-1000) was comparable with the local Black Bengal goats (BBG group; Table 1). The litter size of Black Bengal goats (BBG group) in our experiment was $2 \pm 0.3$ that is comparable with the litter size of $1.96 \pm 0.75$ in Bangladesh as reported by Hassan et al., (2007) (Fig. 1). 
Table.1 Comparison of reproductive performance of Jamunapari and Black Bengal goats following treatment with PMSG and HCG

\begin{tabular}{|l|c|c|c|c|}
\hline Group & JP500 & JP1000 & JP & BBG \\
\hline N & 5 & 5 & 5 & 5 \\
\hline Ovulation Rate & $4.2 \pm 0.37^{\mathrm{c}}$ & $5.6 \pm 0.6^{\mathrm{d}}$ & $1.2 \pm 0.2^{\mathrm{a}}$ & $2.6 \pm 0.5^{\mathrm{b}}$ \\
\hline No. of Kids Born & & & & \\
\hline Singlet & & & 3 & 1 \\
\hline Twin & 2 & 2 & 2 & 3 \\
\hline Triplet & 2 & 2 & & 1 \\
\hline Quadruplet & & 1 & & \\
\hline More than four & nil & nil & nil & nil \\
\hline Total & 10 & 14 & 7 & 10 \\
\hline Number of kids born/doe & $2 \pm 0.5^{\mathrm{b}}$ & $2.8 \pm 0.4^{\mathrm{b}}$ & $1.4^{\mathrm{a}} \pm 0.2^{\mathrm{a}}$ & $2 \pm 0.3^{\mathrm{b}}$ \\
\hline
\end{tabular}

a, b, c, d: Similar alphabets denote homogeneous means (Duncan's Multiple Range Test)

Fig. 1 Mean $10^{\text {th }}$ day (day $0=$ day of estrous) progesterone concentration (ng/ml) of PMSG treated and non-treated Jamunapari does

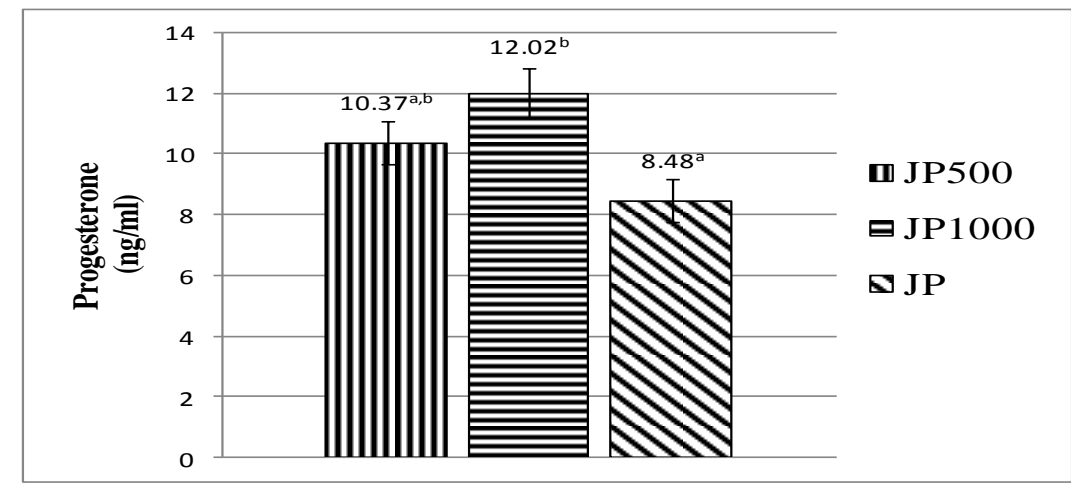

a,b: similar alphabets denote homogenous means (Duncan's Multiple Range Test)

Fig.2 Ultrasonography of ovary containing three corpus lutea

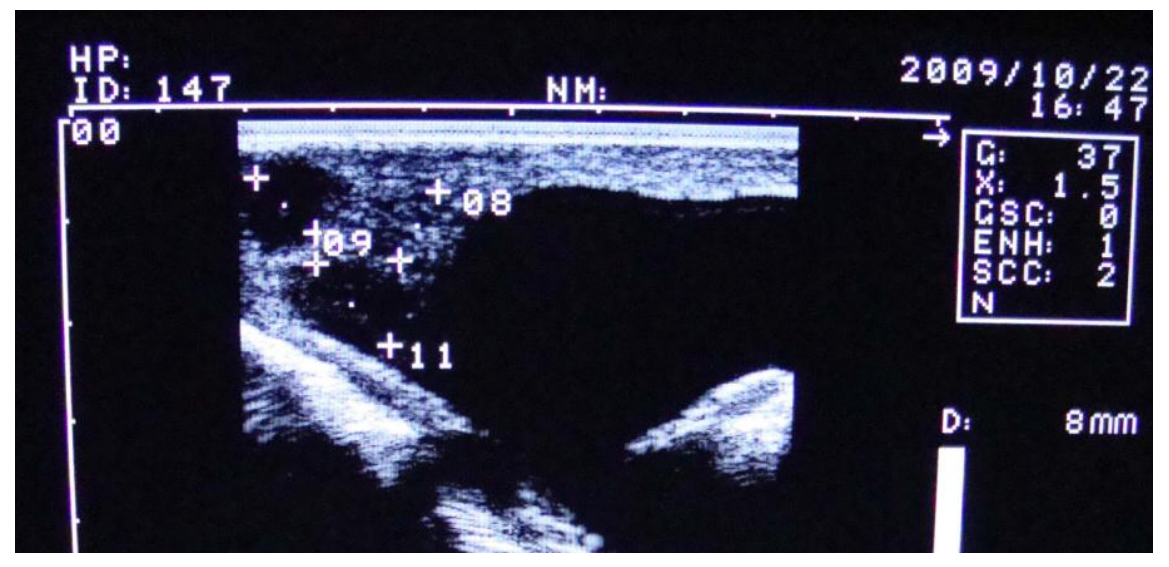


Though the maximum number of ovulation recorded in group JP-500 and JP-1000 was 5 and 7 respectively (data not shown), the maximum number of kids born was only 3 and 4 respectively for the two groups. This indicates that even with greater number of ovulations, there is a maximum limit of embryos that finally occupies the limited uterine space and develops to term.

The tenth day progesterone concentration was significantly greater for PMSG treated groups (JP-500 and JP-1000) compared to nontreated group (JP) of Jamunapari does (Figure 1). This can be explained by greater number of ovulations due to PMSG \& HCG treatments. The progesterone concentration of group JP-1000 was greater than group JP-500 due to higher number of ovulations observed in group JP-1000 compared to group JP-500. This was in accordance with Fonseca et al., 2005 who found greater progesterone concentration with increased number of ovulation in Alpine goats.

Higher progesterone concentration early during the gestation period has been implicated for better growth and viability of the conceptus (Mann et al., 2006) and this might explain the greater number of kids born in group JP-1000 (14) compared to group JP500 (10), though this difference was not significant (Table 1). Probably due to similar reason there was one quadruplet born in group JP-1000.

Overall the data represents that the fecundity of Jamunapari goats can be successfully increased by treatment of 500 IU PMSG and 250 IU HCG. The kidding rate of Jamunapari goats at this drug regimen was comparable with that of local Black Bengal goats. Since the growth rate of Jamunapari goats is almost double that of Black Bengal goats, the cost of hormonal treatment is justified by the greater return from the sale of more number of kids.

\section{Acknowledgements}

The author thanks Dr. S. Batabyal, Professor, Department of Veterinary Biochemistry, WBUAFS and Dr. S. Pan, Professor, Department of Livestock Production and Management for providing the logistic support for hormone ELISA and ultrasonography respectively.

\section{References}

Fonseca, J. F., Torres, C. A. A., Costa, E. P., Maffili, V. V., Carvalho, G. R., Alves, N. G. and Robert, M. A. 2005. Progesterone profile and reproductive performance of estrous-induced Alpine goats given HCG five days after breeding. Anim. Reprod. 2(1): 54-59.

Hassan, M. M., Mahmud, S. N., Islam, S. K. M. A., Miazi, O. F. 2007. A comparative study on reproductive performance and productivity of the Black Bengal and Cross-bred goat at Atrai, Bangladesh. Univ. J. Zool. Rajshahi Univ. 26: 55-57.

Mann G E, Fray M D and Lamming G E. (2006). Effects of time of progesterone supplementation on embryo development and interferon-tau production in the cow. Vet. J. 171(3): 500-503.

Pampukidou, A., Alifakiotis, T., Avdi, M. and Ivanova, R. 2011. Superovulation and embryo transfer in goats by using PMSG and FSH. J. Agri. Sci. Tech. 3(2): 94-97.

Paul, S., Khandoker, M. A. M. Y., Moinuddin, M. A. and Paul, R. C. 2011. Characterization of Black Bengal goat. J. Bangladesh Agril. Univ. 9(1): 61-66.

Rout, P. K., Mandal, A., Roy, R. and Singh, L. B. 1999. Improvement and conservation of Jamunapari goats in their home tract. India, Ministry of Agriculture Report, New Delhi, India. 


\section{How to cite this article:}

Sengupta, D. 2020. Evaluation of Super-ovulatory Protocols in Jamunapari Goats with Pregnant Mare Serum Gonadotropin (PMSG) to Achieve Fecundity Comparable to Black Bengal Goats. Int.J.Curr.Microbiol.App.Sci. 9(11): 1229-1233.

doi: https://doi.org/10.20546/ijcmas.2020.911.144 